\title{
How Close Are Western Cham Language and Bahasa Indonesia in their Structure? A Contrastive Study
}

\author{
Math Safeat, Muhammad Hafiz Kurniawan* \\ Musa Asiah Foundation, Krouch Chmar, Thbong Khmum, Cambodia \\ safir1585@gmail.com \\ Universitas Ahmad Dahlan, Yogyakarta, Indonesia \\ muhammad.kurniawan@enlitera.uad.ac.id*
}

*Corresponding Author

\begin{abstract}
Article Info
ABSTRACT

Article History

Article Received

24 $4^{\text {th }}$ March 2019

Article Reviewed

$28^{\text {th }}$ March 2019

Article Accepted

$9^{\text {th }}$ April 2019

Keywords

Bahasa Indonesia

Cham language

Contrastive analysis

language

Endangerment

Phrase and sentence

structure

Western Cham spoken in Cambodia is categorized as Malay-Polynesian under the West Malay Polynesian with the largest speakers compared to its sister, Eastern Cham spoken in Vietnam. The fallen kingdom of Champa in 1442 brought pervasive and massive change to this language both spoken and writing system. The language contact between these languages to the neighboring language makes these languages survive by adopting the phonotactics of neighboring languages. However, this change can be traced back to its family and this research aims to find and to describe the difference and similarity between Bahasa Indonesia and Cham language using contrastive analysis. This analysis is used to elaborate the phrase structure, and simple clause structure with different voices, negation, and the use of adverb already which has its unique application. This research, which was fully funded by PPSDK (Pusat Pengembangan Stategi Diplomasi dan Kebahasaan) under the Ministry of Education of Republic Indonesia and also supported by Universitas Ahmad Dahlan and Musa Asiah Foundation (YASMA), was conducted in four months in a Muslim private School in Krouch Chmar, Cambodia and has secondary aim to support the development of this language and to preserve it from language endangerment status, because of its limited use in social settings.
\end{abstract}

\section{INTRODUCTION}

Cham language is one of the Austronesian languages spoken in Cambodia and Vietnam, which are known as Western and Eastern Cham [1] which are basically in the same language but different dialect [2]. This happened because basically Western and Eastern Cham were from the same kingdom which was called the Kingdom of Champa and this Kingdom was predicted to exist in 270 [3] which also left the linguistic evidence of stone inscription in the former region of Champa in $4^{\text {th }}$ Century AD [4] and likely this proof make Hendrik Kern think that the origin of Bahasa Indonesia was from the region of Champa [3].

Although the Cham language is considered into Austronesian language and closely related to Malay
Polynesian under the West Malay Polynesian [1, 4]. The language contact between the Cham people and the people surrounding the kingdom happened when the people of Khmer and the Cham people were in contact in the trading activity $[5,6]$. This affected to the change of their language into disyllabic and iambic [2], while the Eastern Cham, it adopt the Vietnam language and make this language change from disyllabic into monosyllabic [2]. However, the language contact happened not only between Cham and Khmer but also between Cham and Malay because the Cham scholars who pursue their education to Malay to learn Islam in the first Islamic teaching in Cambodia[7]. 
The contact between Cham people and Malay because of their will to learn Islam [7] make them change their writing system which was originally adopting the Indic script [2] and they begin to change their writing system to Jawi or Malay Arabic [8] to ease the problem of learning Quran with the Arabic writing system [9]. The change of this writing system was instituted by the arrival of Islam to the Cham society in early $9^{\text {th }}$ century and Islamic teaching to the Cham society [7]. The change of this writing system caused the misspelling of their several words which is written only based on the how they are pronounced. The word which is so terribly misspelled is "bac" or "to read" which is commonly transcribed into "baek". This will make the researcher difficult to trace back the origin of this word, which is from root "baca" in bahasa Indonesia. Therefore, in this paper, the Latin version of Cham language will be based on their original writing system.

The change of this writing system also brought the change to the Cham people's mind about their old writing system which they believed it is related to Buddhism [9] and they use their language only in the particular social settings e.g. family communication, intratribal communication at market and other public places, religious event and ceremony at mosque, and teacher-to-student communication in Muslim private school. When they are in contact with the Khmer people, they will use Khmer; in addition, the educated and ex-migrant worker of Cham can communicate in Malay when they meet Malaysian or Indonesian and even English, French, and Arabic for the Cham scholars.

The use of Cham language in the particular social settings, the status of Cham people which are seen as the minority to the Khmer people [6] after the fall of the kingdom of Champa in 1442 [3], the bilingualism and multilingualism of the native Cham could be seen as the point to language endangerment [10]. Therefore, this paper tried to accommodate the insight towards the recent Champ language which is compared to bahasa Indonesia in their syntactical feature such as phrase and clause so that it is easier for Indonesian - who has to visit the Cham community for doing a research or other activities - to learn and speak Cham language in order to preserve this endangered language.

\section{LITERATURE REVIEW}

\section{a. Review of Related Studies}

Researches about Champ language have been conducted since 1960's but in the different focus and different area of research. In 1967 the research about the phonological pattern on Cham language done by David Blood [11] and the area of research was Cham village in central Vietnam. In 1996, a research which described the change of Chamic language from both dialects, Western and Eastern Cham in the field of phonological drift because of language contact between Western Cham and Mon-Khmer [12].

The next research which related to grammar of Western Cham was conducted by Baumgartner; yet, the data of this research which was from the text which was collected in 1970-1975 [13] might experience change in the actual practice of the Western Cham community in the village which has been in contact not only with Khmer but also with Malay. In the most recent year, 2018, the research about how the Western Cham categorizes something was conducted by Kurniawan, and in this research, the phrase structure of the items described was also elaborated using tree structure [9].

The researches which were conducted by other researchers left a huge gap in which this research could fill it. The first gap is about the year of research which is too long to be the fact and a recent research about Cham language is difficult to be found, the second gap is that the data of those researches might undergo several changes, especially in the recent practices of Western Cham, especially in Svai Khleang village. In the article written by Thurgood about Western Cham in 1996, for example, the word 'hand' was described [tanin] [12] but in the recent practice in the Cham village, Svai Khleang, this word is pronounced [təৈən]. This is only one of differences which might be found in the current practices and the data in this paper shows the recent practices done by the Western Cham in Svai Khleang village.

\section{b. Theoretical Framework}

Due to the fact that the research focus is in contrasting Cham language and bahasa Indonesia in the field of syntax, the theory syntax is used in this paper. The theory about syntax is taken only about phrase and simple clause structure with its variation such as using negation and passive. This paper elaborates particular structure on noun phrase and simple clause structure because the time to collect the data and to learn the Cham language per se for getting the natural spoken languages is so limited. 
The phrase structure, especially in noun phrase is basically divided into four aspects such as determiner, pre-modifier, noun, and post-modifier [14]; however, bahasa Indonesia and Cham language which are included in Malay Polynesian have different phrase structure order which start from noun as the head and followed by modifiers [15] and for numbers, especially cardinal can be positioned before the head [16]. Moreover, the definite article like 'the' is replaced by the demonstratives e.g. ini, itu, tadi, and tersebut for bahasa Indonesia [16] while in Cham the word ini is the same but it is only pronounced $n i$.

In the sentence structure, it focuses on two voices i.e. active and passive [14] because passive voice in Cham language has different pattern from bahasa Indonesia which will be elaborated later in the result and discussion part. In addition, in analyzing the sentence structure, the brackets to analyze the constituent structure [17] are used along with the semantics roles of the verb which is correlated to the case of the subject and object of the verb [17].

The key term of using the case here is only limited to 'dative' for the subject of experiencer verbs, 'nominative' for the transitive subject and nonexperiencer, and 'accusative' for direct object of the verb [17]. The experiencer verbs are limited to 'cognizer' which includes thinker, believer, knower, presumer; 'perceiver' which includes hearer, smeller, feeler, taster; and 'emoter' which takes into account subjects partaking as liker, lover, and hater[17]. Bahasa Indonesia and Cham language have no sign of subject and verb agreement so it is the reason why the case is limited to 'nominative, accusative, and dative' case [18].

\section{METHODOLOGY}

This research fell into the field research and it also uses two main informants as mentioned in acknowledgment part. Therefore, in doing this research, the researcher took three steps in collecting the data and also three steps in analyzing the data, but before it continues to collecting data method and analyzing data method, the area of study for this research is elaborated first.

\section{a. Area of Study}

The area of this research was in the Svai Khleang village, as mentioned earlier. It is located in Kroch Chmar, Thbong Khmum province, Cambodia and Its coordinate is $12^{\circ} 16^{\prime} 17.6^{\prime \prime} \mathrm{N} 105^{\circ} 39^{\prime} 11.3^{\prime \prime} \mathrm{E}$ [19]. It can be reached from the capital city of Phnom Penh in 57 hours to north east by a public transportation, mini bus. Figure 1 and 2 are the exact location of Serpama
Muslim private school in Svai Khleang village, in Krouch Chmar District, Thbong Khmum Province from Phnom Penh.

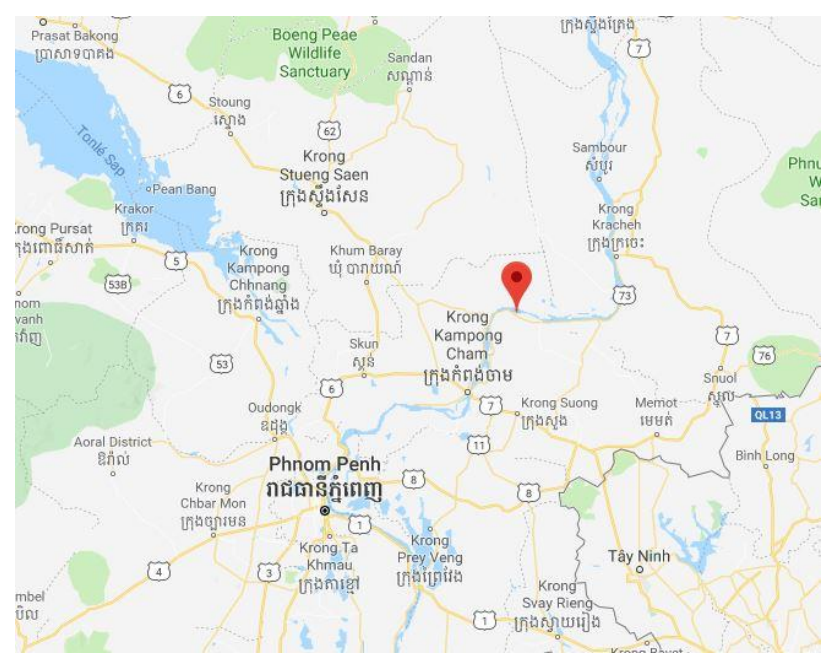

Picture 1. From Phon Penh to Krouch Chmar District (from Google map [19])

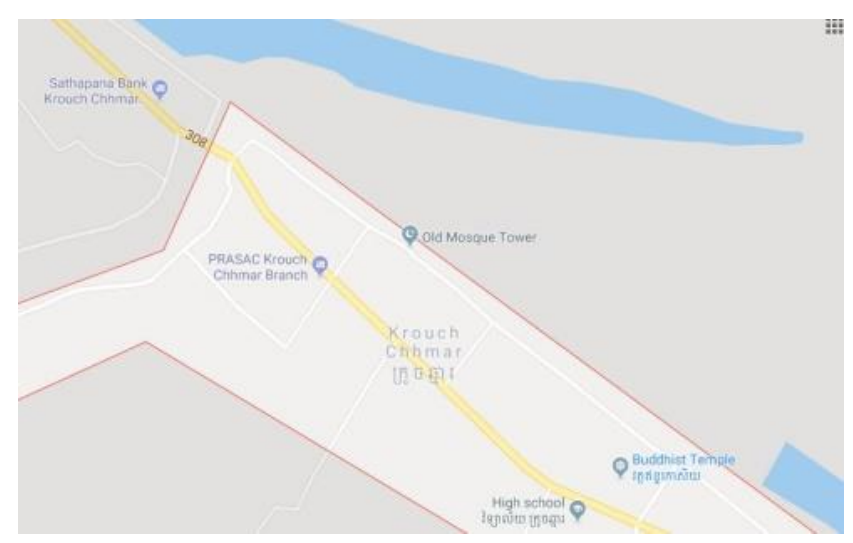

Picture 2. Krouch Chmar District, the school is near of Old Mosque Tower (from Google map [19])

\section{b. Collecting Data Method}

The method of collecting data in the field research realm needs an informant to give the big picture of the language being investigated [20]. Regarding to the ethical issue, this research decided to show the detail information about the people who became the informants of the research and also about the location in which this research took place because this research has an aim to support the Cham community to maintain their language and identity [20]; accordingly, the other researches could be conducted in that community, as this place is historically important.

This research was conducted as the additional activity in the Serpama private school because the primary task which was assigned by PPSDK (Pusat Pengembangan Strategi dan Diplomasi Kebahasaan) under the Ministry of Education of Republic of 
Indonesia to the corresponding author was a teacher who collaborated with the full-time teacher of Serpama private school as the first author of this research in teaching Bahasa Indonesia.

This task as the teacher of Bahasa Indonesia in the Serpama private school gives the opportunity to gain the trust [20] to the Western Cham society, or commonly called full-participation observation [21] so the time spent in this area was used optimally and efficiently to collect as many data as possible although in limited amount of time, four-month duty; in addition, the corresponding author as the researcher as well, can avoid the ambiguous role in the society [20].

The first step in collecting the data was choosing the most appropriate informant for the research. These informants were chosen based on their experience in learning language and they are enthusiastic in language study [22]. The second step is that the first informant was assigned to the text elicitation technique by giving them a number of stimulus sentences as the part of direct elicitation and by having small talks to people in the village as the daily conversation to obtain daily needs and using particular linguistic feature as the indirect elicitation [23]. The text elicited includes noun phrase, varieties of voice in structure, positive and negative statements, and also asked the informants to translate from the contact language to the informant's mother tongue [22] and the other informants have task to judge whether the sentences uttered are natural.

The third method of this was recording their voice when saying the sentences, they were asked to. This is the part of documenting the data [24] while doing the second step as mentioned in the previous paragraph, the researcher also took notes [21] for the lexical and grammatical features of the Cham language so the actual written form of Cham could be documented.

\section{c. Analyzing Data Method}

In this step, the data was analyzed using phonological transcription and also grammatical analysis. The phonological transcription was made to make the reader who interested in this language easy to study and to pronounce. Therefore, in result and discussion part, it could enrich the description of both languages.

The first step of this analyzing data was using the phonetic transcription by IPA (International Phonetics Alphabet) in transcription processes [25]. However, recording devices here were not designed as the proper recording devices for research field because of the limited access to the devices and the place to do the research has great distance to the nearby city; therefore, the recording feature in smartphone/cell phone was used instead [24]. The transcription process was conducted by the first author of this paper, a native Cham.

The second step of analyzing data process was determining the constituent of each word in sentences uttered by the informants e.g. noun, adjective, verb, and adverb [26] and after that it continued to analyze the semantic role of each constituent to obtain the proper case for labeling each word.

The third step was to compare between the sentences in Cham and bahasa Indonesia with the same meaning and grammar but it is different in the order in building the sentences.

\section{RESULT AND DISCUSSION}

This part is divided into two main subparts which are noun phrase structure and the simple sentence structure with two discussions such as 1) simple sentence with negation and other adverbs; and 2) simple sentence structure in passive voice.

\section{a. Noun phrase structure}

Noun phrase structure in bahasa Indonesia and Cham language is similar in the position of noun as a head which is followed by modifiers. It is illustrated in (1.1a) and (1.1b) below.

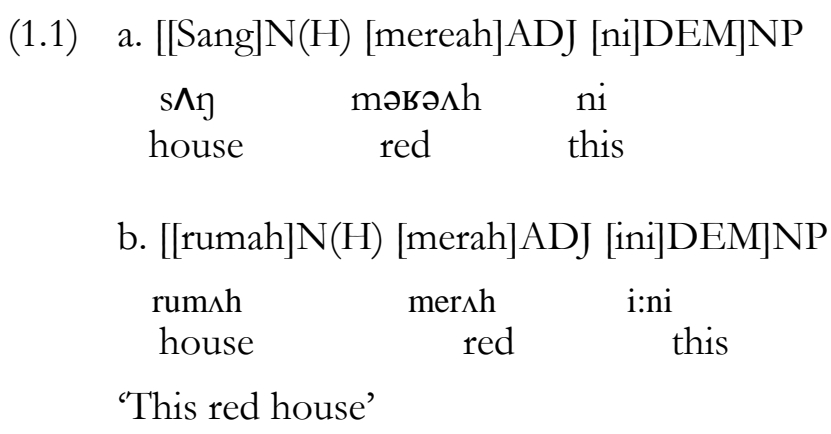

The (1.1a) above explained the position of noun $(\mathrm{N})$ as a head $(\mathrm{H})$ and then it is followed by adjective (ADJ) and demonstrative (DEM). Bahasa Indonesia and Cham from (1.1) above show that the noun phrase structure using adjective and demonstrative is not different at all. Although the modifier is changed into adjective and possessive pronoun, it is no difference at all in their structures.
(1.2)
a. [[Sang]N(H) [prong]ADJ [lan]POSS]NP

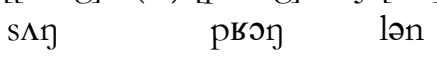
b. [[rumah]N(H) [besar]ADJ [saya]POSS]NP rumsh bəs $\Lambda \mathrm{r} \quad \mathrm{s} \Lambda \mathrm{j} \Lambda$




$$
\begin{aligned}
& \text { house big my } \\
& \text { 'my big house' }
\end{aligned}
$$

The possessive (POSS) pronoun 'my' which is included as determiner [14] in both languages is not different in the noun phrase position as seen above in (1.2a) and (1.2b); even, the position of prepositional phrase (PP) in the noun phrase structure is the same in both languages as seen in (1.3a) and 1.3b) below.

$$
\begin{aligned}
& \text { (1.3) a. [[sang] } \mathrm{N}(\mathrm{H}) \text { [prong]ADJ [lan]POSS } \\
& \text { s } \Lambda \text { y pвon lon } \\
& \text { [[duk]P [[plai]N [Khbob]PN]NP]PP]NP } \\
& \text { to? } \mathrm{p}^{2} \mathrm{~h} \mathrm{I} \quad \mathrm{k}^{\mathrm{h}} \mathrm{p} \text { ○ } \\
& \text { b. [[rumah]N(H) [besar]ADJ [saya]POSS } \\
& \text { rum } \Lambda \text { bəs } \Lambda \mathrm{r} \quad \mathrm{s} \Lambda \mathrm{j} \Lambda \\
& \text { house big my } \\
& \text { [[di]P [[kampung]N [Khbob]PN]NP]PP]NP } \\
& \text { di kampun } \mathrm{k}^{\mathrm{h}} \mathrm{p} \text { op } \\
& \text { in village Khbob }
\end{aligned}
$$

The position of Khbob village is in converse order which begins with the head of the noun phrase 'village' and followed by other noun as the modifier. Although the similarity degree of bahasa Indonesia and Cham in noun phrase is quite high, the position of number in noun phrase is totally different as illustrated below.

$$
\begin{aligned}
& \text { a. [[sang]N(H)[dua]NUM[boh]QNT[ni]DEM]NP } \\
& \text { s } \mathrm{y} \text { duws boh ni } \\
& \text { house two fruit this } \\
& \text { b. [[dua]NUM [rumah]N(H) [ini]DEM]NP } \\
& \text { duws rumsh i:ni } \\
& \text { two house this }
\end{aligned}
$$

'these two houses'

Illustration (1.4a) above shows that the order of NP in Cham language when it comes to number is different from bahasa Indonesia as shown in (1.4b). The order of noun phrase with number in Cham language is $\mathrm{N}(\mathrm{H})+\mathrm{NUM}+\mathrm{QNT}+\mathrm{DEM}$ while in bahasa Indonesia it is only $\mathrm{NUM}+\mathrm{N}(\mathrm{H})+\mathrm{DEM}$.

\section{b. Simple sentence structure}

The next discussion is about the simple sentence structure in Western Cham language which has different structure from Bahasa Indonesia. The difference between Western Cham language

\section{Simple sentence structure with negation and other adverbs}

Simple sentence structure with negative "not" in Western Cham language is unlike Bahasa Indonesia because in Western Cham language the negative word is not closed to verb like in Bahasa Indonesia but it is placed in the last of the sentence. The structure I in (1.5a) and (1.5b) below shows how the Western Cham language uses the negation compared with Bahasa Indonesia.

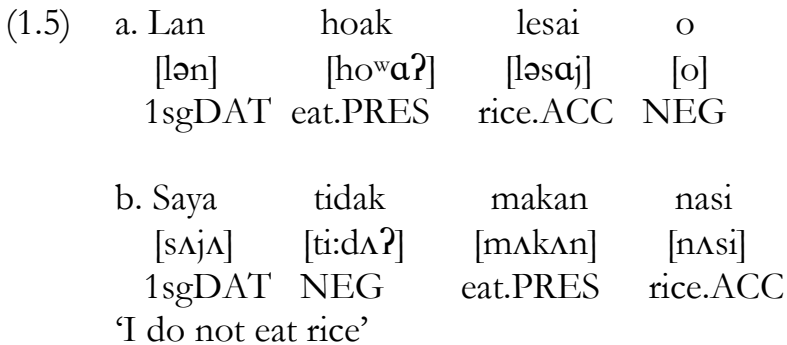

The illustration (1.5a) shows that the structure of Western Cham language is not different from Bahasa Indonesia as in (1.5b) and both of those languages do not have verb agreement between the subject and verb [18].

The positioning negation in the illustration (1.5a) has the same position when the adverb 'much and many' [14] which is pronounced [lo] in the sentence. It is illustrated in (1.6a) below.

$$
\begin{aligned}
& \text { a. Hoi bac siephou lo } \\
& \text { [har] [bac?] [sip } \left.{ }^{\mathrm{h} O u}\right] \text { [lo] } \\
& \text { 2sgDAT read.PRES book.ACC ADV } \\
& \text { b. Anda membaca banyak buku } \\
& {[\Lambda \mathrm{nd} \Lambda] \quad\left[\mathrm{m} \partial \mathrm{mb} \Lambda \mathrm{t} \int \Lambda\right] \quad[\mathrm{b} \wedge \mathrm{n} \Lambda \mathrm{P}] \quad[\mathrm{buku}]} \\
& \text { 2sgDAT read.PRES ADV buku.ACC }
\end{aligned}
$$

The position of adverb 'much and many' as illustrated in (1.6a) has the same structure as in (1.5a). This structure is also the same when Western Cham language uses adverb 'already' or pronounced [ploh jo] which will be completely elaborated in simple sentence structure with adverb of time 'already' because the different use of already for verb and adjective is different. The illustration (1.7a) is the structure of simple sentence with adverb 'already'.

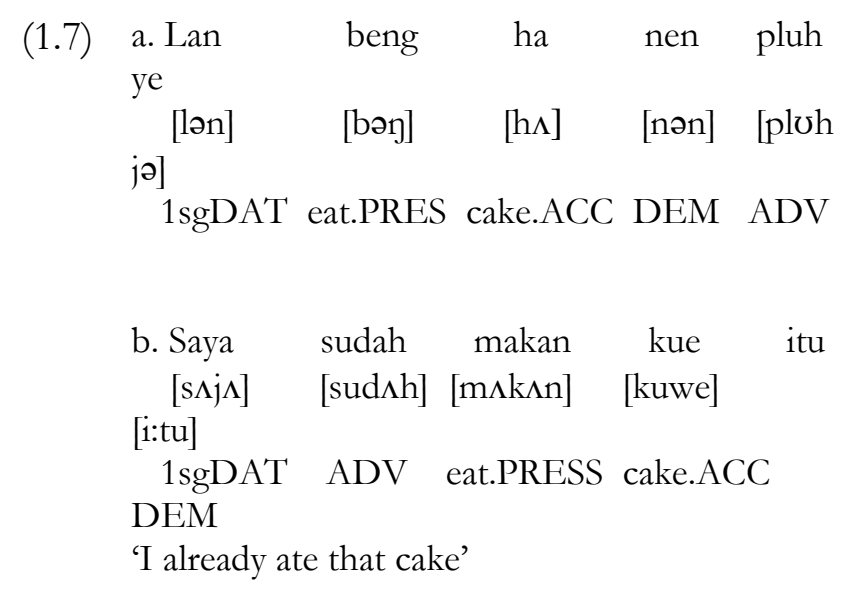

The subject case of those three illustrations (1.5), (1.6), and (1.7) is considered dative because they have perceiver verbs such as eat (taster), and read (see-er) [17]. Moreover, the verbs 'eat' in Western Cham 
language are divided into two types, first is that 'eating rice' which is pronounced [how $\mathrm{a}$ ?], while the second type is 'eating cake' which is pronounced [bəy]. Meanwhile, in Bahasa Indonesia the difference between 'eating cake' and 'eating rice' does not exist.

In illustration (1.7) the predicate which is included in verb, has different from the illustration (1.8) which the predicate is adjective. The adjective in Bahasa Indonesia and Western Cham language has the same structure because both languages do not have any auxiliary verb in adjective predicate[16] as in English [27].

$$
\begin{aligned}
& \text { (1.8) a. Nyu cabkegau ye } \\
& \text { [nu] [t fapkəyaow] [jo] } \\
& 3 \mathrm{sgNOM} \text { healthy.ADJ ADV } \\
& \begin{array}{lll}
\text { b. Dia } & \text { sudah } & \text { sembuh } \\
{[\mathrm{s} \Lambda \mathrm{j} \Lambda]} & {[\operatorname{sud} \Lambda \mathrm{h}]} & {[\text { səmbuh }]}
\end{array} \\
& \text { 3sgDAT ADV healthy.ADJ } \\
& \text { 'He/she already recovered from illness' }
\end{aligned}
$$

The illustration in (1.8a) depicts how the use of word 'already' when it is used with adjective. In this case, the word 'already' which is pronounced [ploh jo] is stressless or shortened into [jo] [17].

\section{Simple sentence structure in passive voice}

The passive structure of Western Cham language is the same in its structure from Bahasa Indonesia, especially the passive structure type 2 [16]. The passive voice of Bahasa Indonesia type 2 is when the verb of the sentence is placed in the last of the sentence [16] as illustrated in (1.9a) and (1.9b) below.

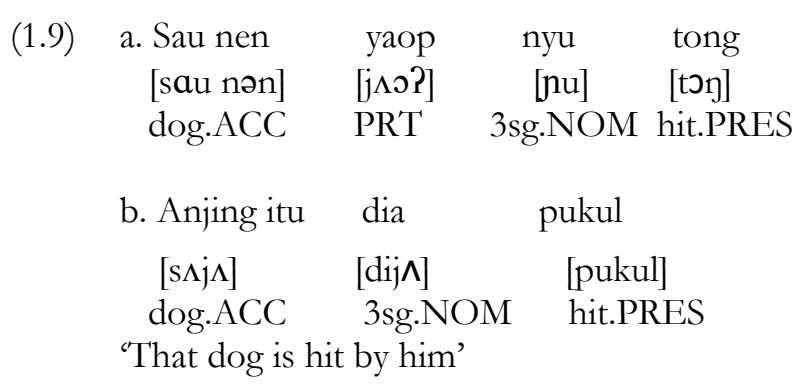

The illustration (1.10a) below also has almost the same structure as in (1.9a); however, the use of verb 'to sell' here should be highlighted because it has the same structure as verb 'to kill', especially the morpheme $\{\mathrm{pa}-\}$.

$$
\begin{aligned}
& \text { (1.10) a. Kan prong nen yaop Hasanah pa.blai } \\
& {\left[\text { kan pron nən] }[\mathrm{j} \Lambda \supset ?][\mathrm{h} \wedge \mathrm{s} \wedge \mathrm{n} \wedge \mathrm{h}]\left[\mathrm{p} \wedge \mathrm{b}^{\ni} \mathrm{l} \Lambda \mathrm{I}\right]\right.} \\
& \text { fish big that.ACC PRT 3sg.NOM } \\
& \text { to.sell.PRES }
\end{aligned}
$$

\author{
b. Ikan besar itu Hasanah jual \\ [ik $\Lambda \mathrm{n}$ bəs $\Lambda \mathrm{r}$ i:tu] [h $\Lambda \mathrm{s} \Lambda \mathrm{n} \Lambda \mathrm{h}] \quad\left[\mathrm{d} z \mathrm{u}^{\mathrm{w} a l}\right]$ \\ fish big that.ACC 3sg.NOM to sell.PRES \\ 'that big fish is sold by Hasanah'
}

The morpheme $\{\mathrm{pa}-\}$ is also used in the word 'to kill' which is pronounced [pamot $\Lambda$ ] which consists of bound morpheme $\{\mathrm{pa}-\}$ and free morpheme mtai $\left[\mathrm{m}^{\curvearrowright} \mathrm{t} \Lambda \mathrm{T}\right]$ and the word 'to sell' also consists of bound morpheme $\left\{\mathrm{pa}^{-}\right\}$and free morpheme blai $\left[\mathrm{b}^{2} \mid \Lambda \mathrm{I}\right]$. Therefore, the meaning of bound morpheme $\{\mathrm{pa}-\}$ here could be 'to make it V3/Adj' in this case 'to make it dead' and 'to make it bought'.

In another case, although in its structure, Western Cham language has similarity to Bahasa Indonesia, one aspect which makes different is the particle (PRT) [j $\Lambda$ ?] in the passive structure. This particle as it is confirmed to the native Cham has no meaning but only to as passive marker. It means that when the sentence in Western Cham language should be changed into passive, this particle should be used.

In addition, the use of particle [j $\Lambda$ o?] in another sentence is totally dissimilar to what is illustrated in (1.9a). The

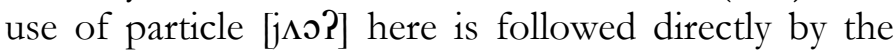
agent or subject of the action. It can be seen in the illustration (1.11a) and (1.12a) below.
(1.11)
a. Lan yaop durui

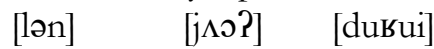
1sg.DAT PRT thorn.NOM
b. Saya tertusuk duri
[s $\Lambda \mathrm{j} \Lambda] \quad$ [tərtusuk] [du:ri]
1sg.DAT stabbed.PRES thorn.NOM
'I am stabbed by a thorn'
(1.12) a. Nyu yaop siupao
[nu] [jᄉ०?] [sijupaow]
3sg.DAT PRT bullet.NOM
b. Dia tertembus peluru
[dij $\Lambda$ [tərtəmbus] [pəluru]
3sg.DAT was hit. PAST bullet.NOM
'He/she was injured by a bullet'

The dative case is also used in (1.11) and (1.12) because the word 'I' and 'he/she' here is the experiencer of being injured by thorn and bullet. Meanwhile the thorn and the bullet in the sentence in (1.11a) and in (1.12a) can be seen as noun which make the cause of why the experiencer feels hurt. 
In Bahasa Indonesia, the word being hurt by thorn is tertusuk and by bullet is tertembus; meanwhile, these words do not exist in Western Cham Language and they are described by the particle yaop, In contrast, when the actor of passive voice is animate, the particle yaop should be followed by the actor and verb as in (1.9) and (1.10).

\section{CONCLUSION}

Although Western Cham language is from MalayoPolenesian under West Malayo-Polenesian has similarities to Bahasa Indonesia, Western Cham language also has dissimilarity to Bahasa Indonesia in its structure. The first is that the similarity is in the noun phrase when noun phrase has demonstrative word like this and that. The position of demonstrative (DEM) is the same in both languages and they have no difference in that noun phrase structure with demonstrative and even prepositional phrase (PP).

The second is that the similarity is when both languages has possessive determine such as my, your, his, and her they position it in the same position as demonstrative. However, the dissimilarity of both languages is when the use of number in noun phrase is used. Western Cham language adds word boh as the quantifier (QUANT) but in Bahasa Indonesia does not.

The third is that the similarity is when both languages, Bahasa Indonesia and Western Cham language, have the structure of simple sentence without negation and other adverbs such as many, much, and already; however, they have slightly different structure when negation, and other adverbs such as much, many, and already appear in the sentence because those adverbs are placed in the last of the sentence.

The fourth is that the similarity between Western Cham language and Bahasa Indonesia is that both languages have the same structure when they are in passive voice, especially the passive voice of Bahasa Indonesia type 2, when the verb of the sentence is placed in the last sentence. However, they still have notable difference because passive in Western Cham language should use particle (PRT) yaop and while Bahasa Indonesia should not. Moreover, the particle yaop can appear as if it is verb when the actor of the action is inanimate such as thorn, and bullet. In Bahasa Indonesia, the actor of the morpheme $\{$ ter- $\}$ in passive will exclude the actor of the action but if it includes inanimate actors such as 'thorn' and 'bullet' it means that the sentence contains meaning 'suddenly and unexpected'. In Western Cham language, however, the verb does not exist and is replaced by the particle yaop but the inanimate actor exists.

This use of particle yaop in passive with the verb still appears for animate and with the verb disappears for inanimate is to mark that the meaning of sentence in first passive rule is that this action is done by someone purposefully; while of the second passive rule is that this action means 'suddenly and unpredicted'. This particle is used because morpheme in Western Cham language is not as complex as in Bahasa Indonesia.

The more interesting to note is that in Western Cham language the morpheme $\{\mathrm{pa}-\}+$ Verb has the meaning 'to make something/someone to be V3/Adj'; therefore in the word pablai which consists of $\{\mathrm{pa}-\}+$ blai or $\{\mathrm{pa}-\}+$ 'buy' means 'to sell' while $\{\mathrm{pa}-\}+$ mtai or $\{\mathrm{pa}-\}+$ 'dead' means to 'kill'.

\section{ACKNOWLEDGEMENT}

This research was fully funded by Pusat Pengembangan Strategi dan Diplomasi Kebahasaan (PPSDK) under the Ministry of Education of Republic Indonesia which collaborated with Yayasan Musa Asiah (YASMA) and Universitas Ahmad Dahlan in doing a mission to spread bahasa Indonesia around the world.

This research also could not be conducted and be finished without the help from the people of Svai Khleang village, Khbop village, and other teachers who work in Serpama under Yayasan Musa Asiah/Musa Asia Foundation in Svai Khleang, Kroch Chmar, Thbong Khmum, Cambodia.

\section{REFERENCES}

[1] Blust, Robert. 2013. The Austronesian Languages. Edited by Paul Sidwell. Revised. Canbera: AsiaPacific Linguistics.

[2] Thurgood, Graham. 2005. Phan Rang Cham. In The Austronesian Languages of Asia and Madagascar, ed. Alexander Adelaar and Nikolaus P. Himmelmann, 489-512. New York: Routledge.

[3] Hall, D.G.E. 1981. A History of South-East Asia. 4th ed. London: Macmillian Press.

[4] Adelaar, Alexander. 2005. The Austronesian Languages of Asia and Madagascar: A Historical Perspective. In The Austronesian Languages of Asia and Madagascar, ed. Alexader Adelaar and Nikolaus P. Himmelmann, 1-41. New York: Routledge.

[5] Thurgood, Graham. 1999. From Ancient Cham to 
Modern Dialects: Two Thousand Years of Language Contact and Change. Honolulu: University of Hawai'i Press.

[6] Chandler, David. 2008. A History of Cambodia. 4th ed. Colorado: Westview Press.

[7] Mohamad Zain, Bin Musa. 2008. Dynamics of Faith: Imam Musa in The Revival of Islamic Teaching in Cambodia. Islam at the Margins: The Muslim of Indochina 3: 59-69.

[8] Stoddard, Allen. 2009. The Cham Muslims of Cambodia: Defining Islam Today and the Validity of the Discourse of Syncretism. In Living on the Margins: Minorities and Borderlines in Cambodia and Southeast Asia, ed. Peter J. Hammer, 235-248. Siem Riep: Center for Khmer Studies.

[9] Kurniawan, Muhammad Hafiz. 2018. Folk Categorizations of Western Champa in Cambodia: A Cognitive Linguistics Studies. ASEAN Journal of Community Engagement 2: 38-54.

[10] Tsunoda, Tasaku. 2006. Language Endangerment and Language Revitalization. Berlin: Walter de Gruyter.

[11] Blood, David. 1967. Phonological Units in Cham. Anthropological Linguistics 9: 15-31.

[12] Thurgood, Graham. 1996. Language Contact and the Directionality of Internal Drift: The Development of Tones and Register in Chamic. Language 72: 1-31.

[13] Baumgartner, Neil I. 1998. A Grammar Sketch of Western (Cambodian) Cham. Papers in Southeast Asian Linguistics No 15: Further Chamic Studies: 120.

[14] Greenbaum, Sidney, and Gerald Nelson. 2002. An Introduction to English Grammar. 2nd ed. Malaysia: Pearson Education.

[15] Ewing, Michael C. 2005. Colloquial Indonesian. In The Austronesian Languages of Asia and Madagascar, ed. Alexander Adelaar and Nikolaus P. Himmelmann, 227-258. London: Routledge.

[16] Sneddon, James Neil. 2010. Indonesian Reference Grammar. 2nd ed. Sydney: Allen \& Unwin.

[17] van Valin, Robert D. 2004. An Introduction to Syntax. Cambridge: Cambridge University Press.

[18] Baker, Mark C. 2015. Case: Its Principles and Its Parameters. Cambridge: Cambridge University Press.

[19] Google. 2019. Krouch Chmar District, Thbong Khmum Province.

[20] Eckert, Penelope. 2013. Ethics in Linguistic Research. In Research Methods in Linguistics, ed. Robert J. Podesva and Devyani Sharma, 11-26. New York: Cambridge University Press.
[21] Moleong, Lexy J. 2015. Metodologi Penelitian Kualitatif. 34th ed. Bandung: PT Remaja Rosdakarya.

[22] Chelliah, Shobhana. 2013. Fieldwork for Language Description. In Research Methods in Linguistics, ed. Robert J. Podesva and Devyani Sharma, 51-73. New York: Cambridge University Press.

[23] Schilling, Natalie. 2013. Survey and Interviews. In Research Methods in Linguistics, ed. Robert J. Podesva and Devyani Sharma, 96-115. New York: Cambridge University Press.

[24] Podesva, Robert J, and Elizabeth Zsiga. 2013. Sound Recordings: Acoustic and Articulatory Data. In Research Methods in Linguistics, ed. Robert J. Podesva and Devyani Sharma, 169-194. New York: Cambridge University Press.

[25] Nagy, Naomi, and Devyani Sharma. 2013. Transcription. In Research Methods in Linguistics, ed. Robert J. Podesva and Devyani Sharma. New York: Cambridge University Press.

[26] Sudaryanto. 1993. Metode dan Aneka Teknik Analisis Babasa: Pengantar Penelitian Wabana Kebudayaan secara Linguistis. Yogyakarta: Duta Wacana University Press.

[27] Larsen-Freeman, Diane, and Marianne CelceMurcia. 2016. The Grammar Book: Form, Meaning, and Use for English Language Teachers. Canada: Cengage Learning. 